\title{
Effect of palmitate-induced steatosis on paraoxonase-1 and paraoxonase-3 enzymes in human-derived liver (HepG2) cells
}

\author{
İnsan kaynaklı karaciğer (HepG2) hücrelerinde palmitat ile oluşturulan yağlanmanın \\ paraoksonaz-1 ve paraoksonaz-3 enzimlerine etkisi
}

\author{
Gülben Sayılan Özgün ${ }^{1}$, Eray Özgün ${ }^{1}$, Kıymet Tabakçığlu ${ }^{2}$, Selma Süer Gökmen ${ }^{1}$, Sevgi Eskiocak ${ }^{1}$
}

Abstract

Aim: Palmitate is one of the most abundant fatty acid in both liver of healthy individuals and in patients with non-alcoholic fatty liver disease. Palmitate-induced steatosis in HepG2 cells is an in vitro non-alcoholic fatty liver disease model to investigate acute harmful effects of fat overaccumulation in the liver. Non-alcoholic fatty liver disease is strongly associated with atherosclerosis. Paraoxonase-1 and paraoxonase-3 are antiatherosclerotic enzymes which are bound to high density lipoprotein in circulation and they are primarily synthesized by liver. There is no study that investigated the effect of palmitate-induced steatosis on paraoxonase- 1 and paraoxonase- 3 enzymes. The aim of present study was to investigate the effect of palmitateinduced steatosis on paraoxonase- 1 and paraoxonase- 3 enzymes in HepG2 cells.

Methods: To induce steatosis, cells were incubated with $0.4,0.7$ and $1 \mathrm{mM}$ palmitate for 24 hours. Cell viability was evaluated by 3-(4,5-Dimethyl-2-thiazolyl)-2,5-diphenyl-2H-tetrazolium bromide assay. Cells were stained with oil red $\mathrm{O}$ and triglyceride levels were measured. Paraoxonase-1 and paraoxonase-3 protein levels were measured by western blotting, their mRNA expression were measured by quantitative PCR and arylesterase activity was measured spectrophotometrically.

Results: All palmitate concentrations caused a significant increase on paraoxonase- 1 mRNA levels. Palmitate concentrations did not cause a significant change on paraoxonase-1 and paraoxonase-3 protein levels, paraoxonase-3 mRNA levels and arylesterase activities.

Conclusion: Our study showed that palmitate-induced steatosis up-regulates paraoxonase-1 mRNA, has no effect on paraoxonase- 1 and paraoxonase-3 protein levels, paraoxonase-3 mRNA and arylesterase activity in HepG2 cells.

Keywords: Palmitate, paraoxonase-1, paraoxonase-3, arylesterase, HepG2, non-alcoholic fatty liver disease.

Öz

Amaç: Palmitat, hem sağlıklı bireylerin hem de non-alkolik karaciğer yağlanması hastalarının karaciğerinde en fazla bulunan yağ asitlerinden biridir. HepG2 hücrelerinde palmitat ile oluşturulan yağlanma, karaciğerdeki yağ birikiminin akut zararlı etkilerinin araştırılmasında kullanılan in vitro non-alkolik yağlı karaciğer hastalığ modelidir. Non-alkolik yağlı karaciğer hastalığı ateroskleroz ile yakından ilişkilidir. Paraoksonaz-1 ve paraoksonaz-3 dolaşımda yüksek dansiteli lipoproteine bağlı anti-aterosklerotik enzimlerdir ve esas olarak karaciğerde sentezlenirler. Palmitat ile oluşturulan yağlanmanın paraoksonaz-1 ve paraoksonaz-3 enzimleri üzerine etkisini araştıran bir çalışma bulunmamaktadır. Bu çalışmanın amacı HepG2 hücrelerinde palmitat ile oluşturulan yağlanmanın paraoksonaz-1 ve paraoksonaz-3 enzimlerine etkisini araştırmaktır.

Yöntemler: Yağlanma oluşturmak için hücreler $0.4,0.7$ ve $1 \mathrm{mM}$ palmitat ile 24 saat inkübe edildi. Hücre canlılığı 3-(4,5-Dimetil-2-tiazolil)-2,5-difenil-2H-tetrazolium bromür testi ile değerlendirildi. Hücreler oil red $\mathrm{O}$ ile boyandı ve trigliserit düzeyleri ölçüldü. Paraoksonaz-1 ve paraoksonaz-3 protein düzeyleri western blot ile, mRNA'ları ise kantitatif PCR ile ve arilesteraz aktivitesi spektrofotometrik olarak ölçüldü.

Bulgular: Tüm palmitat konsantrasyonları paraoksonaz-1 mRNA düzeylerinde anlamlı bir artışa yol açtı. Palmitat konsantrasyonları paraoksonaz-1 ve paraoksonaz-3 protein düzeylerinde, paraoksonaz-3 mRNA düzeylerinde ve arilesteraz aktivitesinde anlamlı bir değişime yol açmadı.

Sonuç: Çalışmamız, HepG2 hücrelerinde palmitat ile oluşturulan yağlanmanın paraoksonaz-1 mRNA düzeyini arttırdığını, paraoksonaz-1 ve paraoksonaz-3 protein düzeylerine, paraoksonaz-3 mRNA düzeylerine ve arilesteraz aktivitesine etkisi olmadığını gösterdi.

Anahtar kelimeler: Palmitat, paraoksonaz-1, paraoksonaz-3, arilesteraz, HepG2, non-alkolik yağlı karaciğer hastalığı.
${ }^{1}$ Trakya University, School of Medicine, Department of Medical Biochemistry, Edirne, Turkey.

${ }^{2}$ Trakya University, School of Medicine, Department of Medical Biology, Edirne, Turkey.

(iD)

GSÖ: 0000-0001-6990-3484

EÖ: 0000-0002-6744-1519

KT: 0000-0002-7345-0825

SSG: 0000-0001-5701-4962

SE: 0000-0002-0813-2345

Ethics Committee Approval: HepG2 cells were commercially available and due to the fact that this study was no human or animal study, no ethical approval has been taken.

Etik Kurul Onayı: HepG2 hücreleri ticari olarak temin edildi ve bu çalışma insan veya hayvan çalışması olmadığı için etik kurul onayı alınmamıştır.

Conflict of Interest: No conflict of interest was declared by the authors.

Çıkar Çatışması: Yazarlar çıkar çatışması bildirmemișlerdir.

Financial Disclosure: The authors declared that this study has received no financial support.

Finansal Destek: Yazarlar bu çalıșma için finansal destek almadıklarını beyan etmişlerdir.

Geliş Tarihi / Received: 24.10.2019

Kabul Tarihi / Accepted: 13.11.2019

Yayın Tarihi / Published: 01.12.2019

Sorumlu yazar / Corresponding author:

Gülben Sayılan Özgün

Adres/Address: Department of Medical Biochemistry, Trakya University School of Medicine 22030 Edirne, Turkey.

e-posta: gulben_syln@hotmail.com

Tel/Phone: +90 5464191946

Fax: +902842357652

Copyright C ACEM 


\section{Introduction}

Non-alcoholic fatty liver disease (NAFLD) can be defined as the presence of hepatic steatosis without significant alcohol consumption and it's the major cause of liver disease with high global prevalence and incidence [1, 2]. NAFLD is associated with metabolic syndrome and there is an increased triglyceride accumulation in hepatocytes of patients with NAFLD [3]. Although NAFLD is a primary liver-related disease, it also affects extra-hepatic organs and regulatory pathways. NAFLD increases risk of diabetes mellitus, cardiovascular and kidney diseases [4]. NAFLD also plays an independent role in the atherogenic dyslipidemia and is strongly associated with atherosclerosis $[3,5]$.

Palmitate is a 16-carbon saturated fatty acid. It is one of the most abundant fatty acid in both liver of healthy individuals and in patients with NAFLD [6]. HepG2 cells are commercially available human-derived hepatoma cells and retain many biological characteristics of hepatocytes. These cells are useful tools in the understanding of hepatic protein biosynthesis [7]. Palmitate-induced steatosis in HepG2 cells is an experimental NAFLD model to investigate acute harmful effects of fat overaccumulation in liver [8].

Paraoxonase (PON)1 and PON3 are the members of PON enzyme family and they are primarily synthesized by liver [9]. In circulation, PON1 and PON3 are bound to high density lipoprotein (HDL) which is the anti-atherosclerotic lipoprotein. HDL mediates reverse cholesterol transport and have antioxidant and anti-inflammatory properties [10]. PON1 and PON3, antioxidant enzymes, prevent oxidation of HDL and low density lipoprotein and therefore prevent atherosclerosis [11]. Although most known PON enzyme activities are paraoxonase and arylesterase, PON1 has mainly paraoxonase and arylesterase activities but all PON enzymes are primarily lactonases [9].

Although there are some reports that investigated PON1 and PON3 mRNA expression [12, 13], PON1 protein levels [14] and activity [15] in patients with NAFLD or experimental NAFLD models, the effect of NAFLD on PON1 and PON3 enzymes have not been fully understood.

There are no studies that investigated the effect of palmitate-induced steatosis on PON1 and PON3 enzymes. Also, we could not encounter any studies which investigate the effect of NAFLD on PON3 protein levels. In the present study, we aimed to investigate the effect of palmitate-induced steatosis on PON1 and PON3 enzymes in HepG2 cells. For this purpose, HepG2 cells were incubated with $0.4,0.7$ and $1 \mathrm{mM}$ palmitate for 24 hours to induce steatosis. PON1 and PON3 protein levels were measured by western blotting, their mRNA expression were measured by quantitative PCR and arylesterase activity was measured spectrophotometrically. With present study, effect of palmitate on PON1 and PON3 enzymes are investigated for the first time and we found that palmitate-induced steatosis upregulates PON1 mRNA, has no effect on PON1 and PON3 protein levels, paraoxonase- $3 \mathrm{mRNA}$ and arylesterase activity in HepG2 cells.

\section{Material and methods}

\section{Chemicals}

Human HepG2 cells were purchased from ATCC (Middlesex, UK). Sodium palmitate, 3-(4,5-Dimethyl-2thiazolyl)-2,5-diphenyl-2H-tetrazolium bromide (MTT), oil red $\mathrm{O}$ and phenylacetate were purchased from Sigma-Aldrich Co. (St. Louis, MO, USA). Minimum Essential Medium, fetal bovine serum (FBS), antibiotic-antimycotic, trypsin-EDTA, RNA isolation kit, High-Capacity cDNA reverse transcription kit, TaqMan probes for PON1, PON3 and glyceraldehyde 3phosphate dehydrogenase (GAPDH) and horseradish peroxidase (HRP) chemiluminescent substrate were purchased from Thermo Fisher (Waltham, MA USA). PON1, PON3, alpha tubulin primary antibodies and goat anti-mouse IgG H\&L HRP secondary antibody were purchased from Abcam (Cambridge, UK). Fatty acid free bovine serum albumin, radioimmunoprecipitation assay (RIPA) lysis buffer system was purchased from Santa Cruz (Heidelberg, Germany). Polyvinylidene fluoride (PVDF) membrane was purchased from Bio-Rad (Hercules, CA, USA). Other chemicals were purchased from Sigma-Aldrich Co. (St. Louis, MO, USA) or Merck (Darmstadt, Germany). All reagents were of analytical grade.

\section{Cell culture and experimental design}

HepG2 cells were cultured in minimum essential medium with glutamine containing $10 \%$ FBS, $1 \%$ sodium pyruvate and $1 \%$ antibiotic-antimycotic $(100 \mathrm{units} / \mathrm{mL}$ penicillin and $100 \mu \mathrm{g} / \mathrm{mL}$ streptomycin and $25 \mu \mathrm{g} / \mathrm{mL}$ of Gibco Amphotericin B) in a humidified environment at $37{ }^{\circ} \mathrm{C}$ and $5 \%$ $\mathrm{CO} 2$ atmosphere.

Sodium palmitate was dissolved in sterile $0.9 \% \mathrm{NaCl}$ at $70{ }^{\circ} \mathrm{C}$ and complexed with $0.7 \mathrm{mM}$ fatty acid free albumin which dissolved in medium without phenol red at $37{ }^{\circ} \mathrm{C}$. For all experimental groups, total albumin concentration in medium was $0.7 \mathrm{mM}$ which was similar to human serum albumin concentrations [16]. Cells were cultured with medium containing 0 (control), 0.4, 0.7 and $1 \mathrm{mM}$ palmitate for 24 hours. Palmitate concentrations were choosen according to previous studies in literature $[8,16]$.

\section{Cell viability assays}

Effect of palmitate on cell viability was evaluated by MTT assay [17]. 104 cells were seeded into the 96 well plates. Cells were cultured with medium containing different palmitate $(0,0.4,0.7$ and $1 \mathrm{mM})$ concentrations for 24 hours. At the end of treatment, mediums were removed and $10 \mu \mathrm{l}$ of MTT $(5 \mathrm{mg} / \mathrm{mL})$ solved in phosphate-buffered saline (PBS) and $100 \mu \mathrm{l}$ of medium without phenol red were added to each well. Cells were then incubated for 4 hours in a humidified environment at $37^{\circ} \mathrm{C}$ and $5 \% \quad \mathrm{CO}_{2}$ atmosphere. MTT-containing medium was then removed and formazan crystals were then dissolved by adding $200 \mu \mathrm{L}$ dimethyl sulfoxide and $25 \mu \mathrm{L}$ Sorensen buffer $(0.1 \mathrm{M}$ glycine, $0.1 \mathrm{M}$ sodium chloride equilibrated to $\mathrm{pH} 10.5$ with 0.1 $\mathrm{M} \mathrm{NaOH}$ ). Optical density of plates were measured using a microplate reader at 570/630 $\mathrm{nm}$ [18]. Optical density of each sample was then compared with the mean optical density value of control group optical density.

\section{Oil red O staining}

Cells were seeded into 6-well plates. After the cells reached $80-90 \%$ confluence, cells were cultured with medium containing different palmitate $(0,0.4, \quad 0.7$ and $1 \mathrm{mM})$ concentrations for 24 hours. After 24 hours, cells were washed with PBS and fixed with $10 \%$ paraformaldehyde for 1 hour. Then cells were washed with $60 \%$ isopropanol and incubated with oil red $\mathrm{O}$ in $60 \%$ isopropanol for 30 minutes. $350 \mathrm{mg}$ oil red O dissolved in $100 \%$ isopropanol as $100 \mathrm{~mL}$ of stock solution. $60 \%$ isopropanol containing oil red $\mathrm{O}$ solution was prepared freshly and filtered before using. After incubation with oil red $\mathrm{O}$, cells were washed with distilled water and photos were taken with inverted microscope [19]. 


\section{Intracellular triglyceride assay}

Cells were seeded into $25 \mathrm{~cm}^{2}$ flask. After the cells reached $80-90 \%$ confluence, cells were cultured with medium containing different palmitate $(0,0.4,0.7$ and $1 \mathrm{mM})$ concentrations for 24 hours. After 24 hours, cells were washed twice with PBS and scrapped with RIPA lysis buffer system. Intracellular triglyceride levels were analyzed by AU 5800 clinical chemistry analyzer (Beckman Coulter lnc, Brea, CA, USA) using its original enzymatic kit (Beckman Coulter lnc, Brea, CA, USA). Protein concentrations were measured according to Lowry et al. [20] by using bovine serum albumin as standard. Triglyceride levels were calculated relative to total protein levels and expressed as fold change relative to control by dividing to mean triglyceride value of control group.

\section{PON1 and PON3 mRNA expression}

Cells were seeded into 6 well plates. After the cells reached $80-90 \%$ confluence, cells were cultured with medium containing different palmitate $(0,0.4,0.7$ and $1 \mathrm{mM})$ concentrations for 24 hours. RNA was isolated from cells by using commercial RNA isolation kit and cDNA was generated from $1 \mu \mathrm{g}$ of total RNA by using commercial high-capacity cDNA reverse transcription kit. These reaction products were subject to quantitative PCR by using TaqMan gene expression assays for PON1 and PON3. GAPDH was used as housekeeping gene. Results were calculated using the $2^{-\Delta \Delta \mathrm{CT}}$ method [21].

\section{Western blot analysis of PON1 and PON3 proteins}

Cells were seeded into $75 \mathrm{~cm}^{2}$ flask. After the cells reached $80-90 \%$ confluence, cells were cultured with medium containing different palmitate $(0,0.4,0.7$ and $1 \mathrm{mM})$ concentrations for 24 hours. After 24 hours, cells were washed twice with PBS and scrapped with RIPA lysis buffer system. Samples were homogenized and then centrifuged at $4{ }^{\circ} \mathrm{C}$ for 10 minutes at $15,000 \times \mathrm{g}$ [22]. Supernatants were used for protein determination and western blotting. Protein concentrations were measured according to Lowry et al. [20] by using bovine serum albumin as standard.

$20 \mu \mathrm{g}$ of total protein was separated by $5-8 \%$ sodium dodecyl sulfate-polyacyrlamide gel electrophoresis and transferred to PVDF membrane by using semi-dry blotting system. Membranes were blocked with $5 \%$ skim milk powder for 1 hour at room temperature. After blocking, membranes were incubated with monoclonal primary antibodies (PON1:1/1000 dilution and PON3:1/1000 dilution) overnight at $4{ }^{\circ} \mathrm{C}$ and then with secondary antibody (HRP goat anti-mouse: 1/10000 dilution) at room temperature for one hour. PON1 and PON3 protein bands were visualised by using electrochemiluminescence detection system with HRP chemiluminescent substrate and were quantified by Image $\mathbf{J}$ [23]. Results were calculated relative to alpha-tubulin as loading control and expressed as fold change relative to control for each blot.

\section{Arylesterase activity}

Cells were seeded into $75 \mathrm{~cm}^{2}$ flask. After the cells reached $80-90 \%$ confluence, cells were cultured with medium containing different palmitate $(0,0.4, \quad 0.7$ and $1 \mathrm{mM})$ concentrations for 24 hours. After 24 hours, cells were washed twice with $\mathrm{PBS}$ and scrapped with $50 \mathrm{mM}$ Tris- $\mathrm{HCl}$ buffer ( $\mathrm{pH}: 8)$ containing $1 \mathrm{mM} \mathrm{CaCl} 2,1 \%$ protease inhibitor cocktail and $0.1 \%$ Triton-X100. Arylesterase activity was determined by the measuring initial rate of substrate hydrolysis at $270 \mathrm{~nm}$ in the assay mixture containing $1 \mathrm{mM} \mathrm{CaCl} 2,2 \mathrm{mM}$ phenylacetate in $50 \mathrm{mM}$ Tris- $\mathrm{HCl}$ buffer ( $\mathrm{pH}$ 8.0) [24, 25]. Measurements were performed at $25^{\circ} \mathrm{C}$ and the blank sample containing incubation mixture without cell lysate was run simultaneously for the correction of spontaneous substrate breakdown. Results were calculated relative to total protein levels and expressed as fold change relative to control.

\section{Statistical analysis}

Results were given as means \pm standard deviation (SD). The one-way analysis of variance test was used for comparison of biochemical parameters among the groups, and then, Tukey and Tamhane post-hoc tests were used for multiple comparisons when the significant difference obtained. SPSS 20.0 (IBM SPSS Inc., Chicago, IL, USA) statistical software was used for statistical analysis. $\mathrm{P}$ value $<0.05$ was considered as statistical significant.

\section{Results}

The mean percentages of cell viabilities of palmitateincubated cells were $85 \%$ for $0.4 \mathrm{mM}$ palmitate, $76 \%$ for $0.7 \mathrm{mM}$ palmitate and $63 \%$ for $1 \mathrm{mM}$ palmitate. All palmitate concentrations $(0.4,0.7,1 \mathrm{mM})$ caused a significant decrease on cell viabilities as compared with control $(\mathrm{P}<0.05$ for all). Increasing palmitate concentrations $(0.4,0.7,1 \mathrm{mM})$ caused a significant decrease on cell viabilities $(\mathrm{P}<0.05$ for all) (Figure 1$)$.

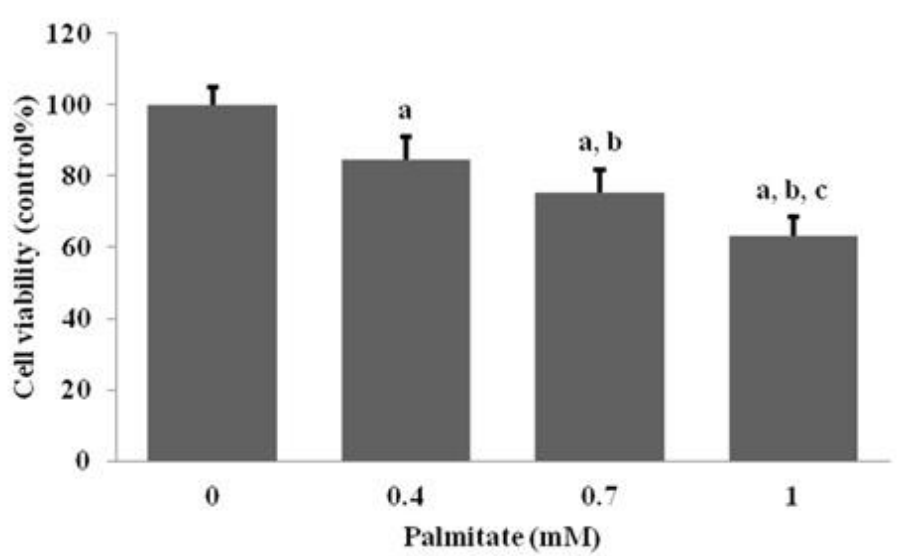

Figure 1: Effect of palmitate on cell viabilities of HepG2 cells. Results are expressed as mean $\pm \mathrm{SD}$ of twenty four results for all groups, a: $\mathrm{p}<0.05$, compared with control, $\mathrm{b}$ : $\mathrm{p}<0.05$, compared with 0.4 $\mathrm{mM}$ palmitate-incubated cells, c: $\mathrm{p}<0.05$, compared with $0.7 \mathrm{mM}$ palmitate-incubated cells.

Palmitate-incubated HepG2 cells were stained with oil red $\mathrm{O}$ to show intracellular lipid content. Increasing palmitate concentrations $(0.4,0.7,1 \mathrm{mM})$ caused an increase on intracellular lipid content of HepG2 cells which were visually observed microscopically by oil red $\mathrm{O}$ staining (Figure 2a).

Intracellular triglyceride levels of palmitate-incubated cells were 1.12-fold, 1.43-fold and 1.77-fold for $0.4,0.7$ and 1 $\mathrm{mM}$ palmitate, respectively. All palmitate concentrations $(0.4$, 0.7, $1 \mathrm{mM}$ ) caused a significant increase on intracellular triglyceride levels as compared with control $(\mathrm{P}<0.05$ for all). Also increasing palmitate concentrations $(0.4,0.7,1 \mathrm{mM})$ caused a significant increase on intracellular triglyceride levels $(\mathrm{P}<0.05$ for all) (Figure 2b).

PON1 mRNA expression of palmitate-incubated cells were 2.09-fold, 1.82-fold and 1.79-fold for 0.4, 0.7 and $1 \mathrm{mM}$ palmitate, respectively. PON1 mRNA expression in 0.4, 0.7 and $1 \mathrm{mM}$ palmitate incubated cells were significantly increased as compared to those in control cells $(\mathrm{P}<0.05$ for all) (Figure $3 \mathrm{a})$.

PON1 protein levels of palmitate-incubated cells were 1.11-fold, 1.07-fold and 0.97-fold for $0.4,0.7$ and $1 \mathrm{mM}$ palmitate, respectively. There was no significant difference 
between PON1 protein levels of groups ( $p>0.05$ for all) (Figure $3 b)$.

PON3 mRNA expression of palmitate incubated cells were 0.88 -fold, 0.95 -fold and 0.98-fold for $0.4,0.7$ and $1 \mathrm{mM}$ palmitate, respectively. There was no significant difference between PON3 mRNA expression of groups ( $p>0.05$ for all) (Figure 3a).

PON3 protein levels of palmitate-incubated cells were 1.21-fold, 1.26-fold and 1.20-fold for $0.4,0.7$ and $1 \mathrm{mM}$ palmitate, respectively. There was no significant difference between PON3 protein levels of groups ( $p>0.05$ for all) (Figure $3 b)$.

\section{A)}

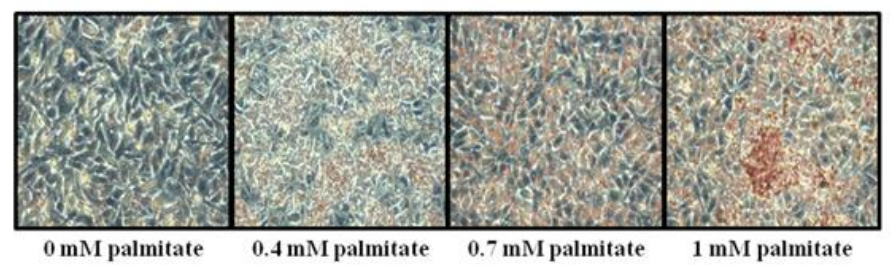

B)

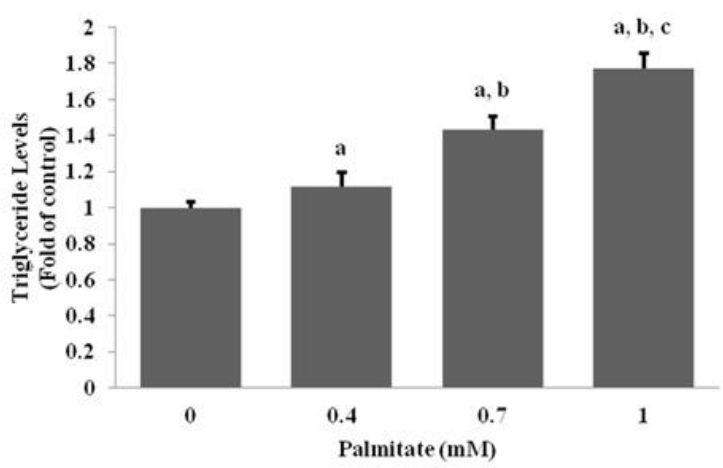

Figure 2: Effect of palmitate on steatosis in HepG2 cells. a) Microscopic images of oil red $\mathrm{O}$ stained (x400 magnification) and b) intracellular triglyceride levels of HepG2 cells. Data are expressed as the mean $\pm \mathrm{SD}$ of six results from three independent experiments for all groups, a: $\mathrm{p}<0.05$, compared with control, $\mathrm{b}$ : $\mathrm{p}<0.05$, compared with $0.4 \mathrm{mM}$ palmitate-incubated cells, c: $\mathrm{p}<0.05$, compared with $0.7 \mathrm{mM}$ palmitateincubated cells.

Arylesterase activities of palmitate incubated cells were 1.04-fold, 1.03-fold and 1.04-fold for $0.4,0.7$ and $1 \mathrm{mM}$ palmitate, respectively. There was no significant difference between arylesterase activities of groups ( $p>0.05$ for all) (Figure 4).

\section{Discussion}

Palmitate-induced steatosis in HepG2 cells is an in vitro NAFLD model to investigate acute harmful effects of fat overaccumulation in the liver [8]. In our study, increasing palmitate concentrations significantly increased steatosis and decreased cell viability in HepG2 cells. Our results confirmed steatosis and cytotoxicity caused by palmitate and were compatible with the literature [26, 27].

For the first time, the effect of palmitate-induced steatosis on PON1 and PON3 enzymes in HepG2 cells and the effect of NAFLD on PON3 protein levels were investigated with the present study. We showed that palmitate at different concentrations $(0.4,0.7$ and $1 \mathrm{mM})$ increases PON1 mRNA expression, but it does not change PON1 protein level and arylesterase activity in HepG2 cells.
A)

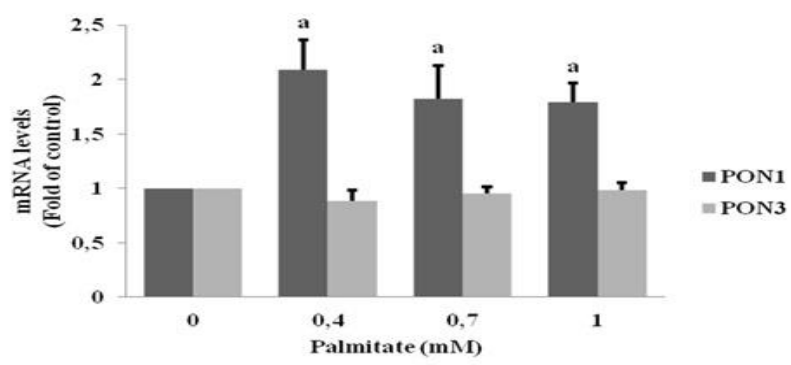

B)

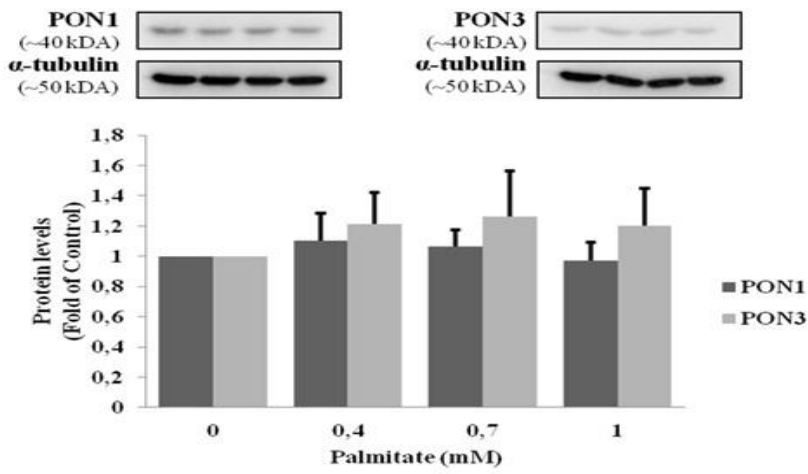

Figure 3: Effect of palmitate on PON1 and PON3. a) mRNA and b) protein levels in HepG2 cells. Data are expressed as the mean \pm SD of five results from five independent experiments for protein levels and nine results for mRNA levels from three independent experiments for all groups, a: $\mathrm{p}<0.05$, compared with control.

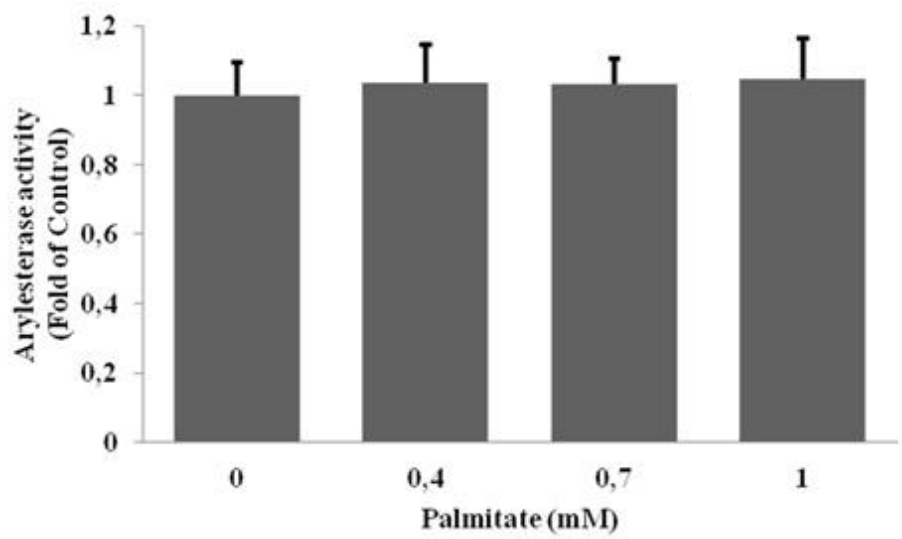

Figure 4: Effect of palmitate on arylesterase activity in HepG2 cells. Data are expressed as the mean \pm SD of twelve results from three independent experiments for all groups.

Our result indicating that PON1 mRNA expression increases in palmitate-induced steatosis supports Desai et al. [14] who reported that liver PON1 mRNA expression increases in paediatric non-alcoholic steatohepatitis. It is known that PON1 prevents oxidative stress and fights with inflammation [11]. It was reported that oxidative stress $[28,29]$ and inflammation [30, 31] are increased in palmitate-induced steatosis in HepG2 cells. An increase in PON1 mRNA expression in palmitate-induced steatosis in HepG2 cells may be associated with cell defense against to oxidative stress and/or inflammation.

PON enzymes have different activities for different substrates. PON1 has mainly arylesterase activity whereas PON3 has very low arylesterase activity [9]. In the present study, although palmitate-induced steatosis increased PON1 mRNA expression in HepG2 cells, it did not change PON1 protein levels and arylesterase activities. Our arylesterase activity results are compatible with Kudchodkar et al. [32] who reported dietary tripalmitin treatment does not alter PON1 activity in rats and also 
compatible with Bosham et al. [33] who reported palmitic acid composition of HDL is not associated with the PON1 activity. Whereas Wang et al. [15] reported that oleic acid-induced NAFLD decreases PON activity in L02 cells. On the other hand, Gomez-Lechon et al. [8] reported that, oleic acid-induced steatosis represents chronic cell model of NAFLD whereas palmitate-induced steatosis represents acute harmful effects of fat overaccumulation. This may be responsible for the difference between PON activities of these two studies. Desai et al. [14] also reported that liver PON1 protein levels are increased in paediatric non-alcoholic steatohepatitis. Whereas we found that palmitate-induced steatosis does not change PON1 protein levels. Unchanged PON1 protein levels in palmitate-induced steatosis could have resulted from the incubation of cells with palmitate for a limited time. It is also known that palmitate induces endoplasmic reticulum stress and inhibits protein synthesis [34]. This may also be responsible from unchanged PON1 proteins and arylesterase activities in our study.

PON3 is not as well studied protein such as PON1. In the present study, for the first time, we showed that PON3 mRNA expression and protein levels are not changed in palmitate-induced steatosis. PON3 mRNA results of our study were compatible with the previous NAFLD animal studies $[12,13]$. Our finding indicating that PON3 mRNA and protein levels do not change in palmitate-induced steatosis in HepG2 cells points out that PON3 enzyme is not affected by increased oxidative stress and inflammation [28-31]. The finding of Reddy et al. [35] who reported that, different from PON1, PON3 is not regulated by oxidized lipids supports this idea.

Although PON1 and PON3 are the members of the same enzyme family and they have many similarities, we found that lipoic acid up-regulates PON3 but down-regulates PON1 mRNA expression, and caffeine increases PON1 protein levels but does not change PON3 protein levels in HepG2 cells in our previous studies $[24,36]$. Taking into consideration the findings we have mentioned above, we can say that PON1 and PON3 are regulated by different mechanisms.

Limitation of present study is not to able to show any PON3 enzyme activity because PON3 lactonase activities are below or very close to detection limits in cell lysates with assay methods using dihydrocoumarin and decanolactone [37]. Also this is an in vitro study and it needs to be supported by future animal and human studies.

In conclusion, we showed that palmitate-induced steatosis up-regulates PON1 mRNA expression but it does not change PON1 and PON3 protein levels, PON3 mRNA expression and arylesterase activities in HepG2 cells.

\section{References}

1. Chalasani N, Younossi Z, Lavine JE, Diehl AM, Brunt EM, Cusi K, et al. The diagnosis and management of non-alcoholic fatty liver disease: practice Guideline by the American Association for the Study of Liver Diseases, American College of Gastroenterology, and the American Gastroenterological Association. Hepatology. 2012;55:2005-23.

2. Younossi ZM, Koenig AB, Abdelatif D, Fazel Y, Henry L, Wymer, M. Global epidemiology of nonalcoholic fatty liver disease-Meta-analytic assessment of prevalence, incidence, and outcomes. Hepatology. 2016;64:73-84.

3. DeFilippis AP, Blaha MJ, Martin SS, Reed RM, Jones SR, Nasir K, et al. Nonalcoholic fatty liver disease and serum lipoproteins: the Multi-Ethnic Study of Atherosclerosis. Atherosclerosis. 2013;227:429-36.

4. Byrne CD, Targher G. NAFLD: a multisystem disease. J Hepatol. 2015; 62: $47-64$

5. Sookoian S, Pirola CJ. Non-alcoholic fatty liver disease is strongly associated with carotid atherosclerosis: a systematic review. J Hepatol. 2008;49:600-07.

6. Araya J, Rodrigo R, Videla LA, Thielemann L, Orellana M, Pettinelli, P et al. Increase in long-chain polyunsaturated fatty acid $n-6 / n-3$ ratio in relation to hepatic steatosis in patients with non-alcoholic fatty liver disease. Clin Sci (Lond). 2004;106:635-43.

7. Bouma ME, Rogier E, Verthier N, Labarre C, Feldmann G. Further cellular investigation of the human hepatoblastoma-derived cell line HepG2: morphology and immunocytochemical studies of hepatic-secreted proteins. In Vitro Cell Dev Biol. 1989;25:267-75.

8. Gómez-Lechón MJ, Donato MT, Martínez-Romero A, Jiménez N, Castell JV, O'Connor JE. A human hepatocellular in vitro model to investigate steatosis. Chem Biol Interact. 2007;165:106-16.

9. She ZG, Chen HZ, Yan Y, Li H, Liu DP. The human paraoxonase gene cluster as a target in the treatment of atherosclerosis. Antioxid Redox Signal. 2012; 16:597-632.

10. Podrez EA. Anti-oxidant properties of high-density lipoprotein and atherosclerosis. Clin Exp Pharmacol Physiol. 2010;37:719-25.

11. Précourt LP, Amre D, Denis MC, Lavoie JC, Delvin E, Seidman E, et al The three-gene paraoxonase family: physiologic roles, actions and regulation. Atherosclerosis. 2011;214:20-36.

12. Hussein O, Zidan J, Abu Jabal K, Shams I, Szvalb S, Grozovski M, et al. Paraoxonase activity and expression is modulated by therapeutics in experimental rat nonalcoholic Fatty liver disease. Int $\mathbf{J}$ Hepatol. 2012;2012:265305.

13. Pereira RR, de Abreu IC, Guerra, JF, Lage NN, Lopes JM, Silva M, et al. Açai (Euterpe oleracea Mart.) Upregulates Paraoxonase 1 Gene Expression and Activity with Concomitant Reduction of Hepatic Steatosis in High-Fat Diet-Fed Rats. Oxid Med Cell Longev. 2016;2016:8379105.

14. Desai S, Bake SS, Liu W, Moya DA, Browne RW, Mastrandrea L, et al. Paraoxonase 1 and oxidative stress in paediatric non-alcoholic steatohepatitis. Liver Int. 2014;34:110-17.

15. Wang B, Yang RN, Zhu YR, Xing JC, Lou XW, He YJ, et al Involvement of xanthine oxidase and paraoxonase 1 in the process of oxidative stress in nonalcoholic fatty liver disease. Mol Med Rep. 2017; 15:387-95.

16. Yang X, Chan C. Repression of PKR mediates palmitate-induced apoptosis in HepG2 cells through regulation of Bcl-2. Cell Res. 2009;19:469-86.

17. Mosmann T. Rapid colorimetric assay for cellular growth and survival: application to proliferation and cytotoxicity assays. J Immunol Methods. 1983;65:55-63

18. Ahmadian S, Barar J, Saei AA, Fakhree, MA Omidi Y. Cellular toxicity of nanogenomedicine in MCF-7 cell line: MTT assay. J Vis Exp. 2009;26:1191.

19. Jang E, Shin MH, Kim KS, Kim Y, Na YC, Woo HJ, et al. Antilipoapoptotic effect of Artemisia capillaris extract on free fatty acidsinduced HepG2 cells. BMC Complement Altern Med. 2014;14:253.

20. Lowry OH, Rosebrough NJ, Farr AL, Randall RJ. Protein measurement with the Folin phenol reagent. J Biol Chem. 1951;193:265-75.

21. Livak KJ, Schmittgen TD. Analysis of relative gene expression data using real-time quantitative PCR and the 2(-Delta Delta C(T)) Method. Methods. 2001;25:402-8.

22. Beltowski J, Jamroz-Wiśniewska A, Borkowska E, Wójcicka G. Differential effect of antioxidant treatment on plasma and tissue paraoxonase activity in hyperleptinemic rats. Pharmacol Res. 2005;51:52332.

23. Schneider CA, Rasband WS, Eliceiri KW. NIH Image to ImageJ: 25 years of image analysis. Nat Methods. 2012;9:671-75.

24. Ozgun E, Sayilan Ozgun G, Tabakcioglu K, Suer Gokmen S, Sut N, Eskiocak S. Effect of lipoic acid on paraoxonase-1 and paraoxonase-3 protein levels, mRNA expression and arylesterase activity in liver hepatoma cells. Gen Physiol Biophys. 2017;36:465-70.

25. Gan KN, Smolen A, Eckerson HW, La Du BN. Purification of human serum paraoxonase/arylesterase. Evidence for one esterase catalyzing both activities. Drug Metab Dispos. 1991;19:100-6.

26. Wang GL, Fu YC, Xu WC, Feng YQ, Fang SR, Zhou XH. Resveratrol inhibits the expression of SREBP1 in cell model of steatosis via Sirt1FOXO1 signaling pathway. Biochem Biophys Res Commun. 2009;380:64449.

27. Gorgani-Firuzjaee S, Adeli K, Meshkani R. Inhibition of SH2-domaincontaining inositol 5-phosphatase (SHIP2) ameliorates palmitate inducedapoptosis through regulating Akt/FOXO1 pathway and ROS production in HepG2 cells. Biochem Biophys Res Commun. 2015;464:441-46.

28. Liu JF, Ma Y, Wang Y, Du ZY, Shen JK, Peng HL. Reduction of lipid accumulation in HepG2 cells by luteolin is associated with activation of AMPK and mitigation of oxidative stress. Phytother Res. 2011;25:588-96.

29. Ma S, Yang D, Li D, Tan Y, Tang B, Yang Y. Inhibition of uncoupling protein 2 with genipin exacerbates palmitate-induced hepatic steatosis. Lipids Health Dis. 2012;11:154. 
30. Choi YJ, Choi SE, Ha ES, Kang Y, Han SJ, Kim DJ, et al. Involvement of visfatin in palmitate-induced upregulation of inflammatory cytokines in hepatocytes. Metabolism. 2011;60:1781-89.

31. Joshi-Barve S, Barve SS, Amancherla K, Gobejishvili L, Hill D, Cave $\mathrm{M}$, et al. Palmitic acid induces production of proinflammatory cytokine interleukin-8 from hepatocytes. Hepatology. 2007;46:823-30.

32. Kudchodkar BJ, Lacko AG, Dory L, Fungwe TV. Dietary fat modulates serum paraoxonase 1 activity in rats. J Nutr. 2000;130:2427-33.

33. Boshtam M, Razavi AE, Pourfarzam M, Ani M, Naderi GA, Basati G, et al. Serum paraoxonase 1 activity is associated with fatty acid composition of high density lipoprotein. Dis Markers. 2013;35:273-80.

34. Perry BD, Rahnert JA, Xie Y, Zheng B, Woodworth-Hobbs ME, Price SR. Palmitate induced ER stress and inhibition of protein synthesis in cultured myotubes does not require Toll-like receptor 4. PLoS One. 2018;13:e0191313.

35. Reddy ST, Wadleigh DJ, Grijalva V, Ng C, Hama S, Gangopadhyay A. Human paraoxonase-3 is an HDL-associated enzyme with biological activity similar to paraoxonase-1 protein but is not regulated by oxidized lipids. Arterioscler Thromb Vasc Biol. 2001;21:542-47.

36. Sayılan Özgün G, Özgün E, Tabakçıŏlu K, Süer Gökmen S, Eskiocak S, Çakır E. Caffeine Increases Apolipoprotein A-1 and Paraoxonase-1 but not Paraoxonase-3 Protein Levels in Human-Derived Liver (HepG2) Cells. Balkan Med J. 2017;34:534-39.

37. Draganov DI, Stetson PL, Watson CE, Billecke SS, La Du BN. Rabbit serum paraoxonase 3 (PON3) is a high density lipoprotein-associated lactonase and protects low density lipoprotein against oxidation. J Biol Chem. 2000;275:33435-42. 